\section{Methodik der Hormonsforschung}

Von Dr. Christian Bomskov. Band I : Schilddrüse, Nebenschilddrüse, Nebennierenrinde, Nebennierenmark, Pankreas. Pp. xxi +716 . (Leipzig: Georg Thieme, 1936.) 54 gold marks.

Dr. Christian Bomskov has undertaken the production of a reference work dealing with all the methods used in the investigation of hormones. The first volume contains a general discussion of methods, and special sections dealing with the thyroid, the parathyroids, the suprarenal cortex and medulla and insulin.

It would be impossible for one man to prepare a critical review of so large a field, and those who have specialized will be able to criticize details, but there can be no doubt that Dr. Bomskov has produced a work that will be very useful to those who wish to know the details of the experimental methods in use. Most of the important methods are described in full detail, and references are given to descriptions of other methods.

The general discussion is divided into sections dealing with surgical methods, histological methods, biological methods and chemical methods. These are each discussed in detail. For example, the section on biological methods deals, among other things, with the obtaining of samples of blood, stomach tubes, injections, weighing, measuring the body temperature, the registration of respiration and blood pressure, isolated hearts, perfusion and isolated plain muscle.

Each of the special sections is subdivided in the same way and the general arrangement is so good that it is easy to find any particular piece of information without reference to the index. The surgical part of each section contains full instructions, illus. trated by diagrams and photographs, for removing each gland from all the commoner laboratory animals. The histological part discusses special methods appropriate to each gland and gives photomicrographs of the appearance of the glands. The biological part discusses all the effects which the different hormones produce, and methods of assay. The chemical part gives methods of isolation, chemical assay and, where possible, methods of synthesis.

This book meets a definite need and can be warmly recommended as a book of reference. It gives a reasonably complete list of the methods available, including the bad methods with the good methods, without much attempt to discriminate between them.

\section{Lehrbuch der Mineralogie}

Von Prof. Walter Schmidt und Dr. E. Baier. Pp. vi +320 . (Berlin : Gebrüder Borntraegar, 1935.) 14 gold marks.

THE two authors of this text-book are in charge of the tuition in mineralogy at the Berlin Technisch $\Theta$ Hochschule. Mineralogy is a science which impinges upon several other sciences, especially geology, physics and chemistry and the number of students who have to acquire at least a general acquaintance with it tends steadily to grow. Prof. W. Schmidt is responsible for the text in general, while the special sections in smaller type have been contributed by Dr. E. Baier, his assistant.

The book is in reality in two parts, although not definitely so divided. The first part, which forms a general introduction to the subject, is occupied with such parts of crystallography, optics, chemistry and geology as apply to mineralogy. The treatment is confined to general principles ; nothing, for example, is said about goniometers, refractometers or other apparatus. The part includes interesting chapters upon the classes of crystal symmetry, the X-ray study of crystal structure, geochemistry and paragenesis. In the sccond part the important characters of the principal mineral species are concisely yet fully described, the arrangement being by elements, sulphides, oxides, silicates, etc., and halogens.

The numerous illustrations greatly add to the value of the book; thanks to the calendered paper used, they are clearly printed, but, on the other hand, the shiny surface is irksome to the reader. Mention should be made of the excellent figures in colour which are inserted at the end, representing a quartz wedge between crossed nicols and uniaxial and biaxial interference figures. Subject and mineral indexes facilitate reference to the book, and the clarity of the exposition throughout is admirable.

\section{Back in the Stone Age:}

the Natives of Central Australia. By Dr. C. Chewings. Pp. $\mathrm{xx}+161+23$ plates. (Sydney and London: Angus and Robertson, Ltd., 1936.) 7s. 6d.

Dr. Chewrigs's experience of the blackfellow dates back to 1881 , when he took up a grant of land in the MacDonnell Ranges of C'entral Australia. The tribes with whom he then came into contact were the Aranda (Arunta) and Loritja described in detail by C. Strehlow, a missionary of the Hermannsburg Mission, more than thirty years ago. When Dr. Chewings first met them, they were living literally in the stone age, their only cutting implements being of stone. He describes their daily life, their social organization and magical beliefs and practices as they presented themselves to the squatter, but with certain explanatory additions to make them intelligible to the ordinary reader, which he has gleaned from the work of Strehlow and Spencer and Gillen. His actual experiences as an employer of the blackfellow in the work of the station and in his contacts with them and their lubras tell us even more of their characters and capacities than his account of their customs.

Notwithstanding the reserve policy and the care of the Governments for the aborigines, Dr. Chewings thinks the drift towards the centres of civilization is inevitable and the ultimate fate of this people extinction. This opinion, based on long experience and understanding of the blackfellow, cannot be ignored; but the Federal Government has already carried out some of the measures advocated by the author, and experience elsewhere in analogous conditions among backward peoples suggests that extinction is by no means so inevitable a fate as he thinks it to be. 